\title{
Ironbark and stone: Place and belonging in the nature novels of Inga Simpson
}

\author{
Jane Frank \\ j.frank@griffith.edu.au
}

\begin{abstract}
This article discusses Sunshine Coast writer Inga Simpson's nature writing in three recent novels, Mr Wigg (2013), Nest (2014b) and Where the Trees Were (2016c). It addresses Simpson's self-categorisation as a nature writer, and shows how the recurrent motif of sacred trees allows three introspective protagonists to reach new understandings of universal themes: loss of love and innocence, ageing, inheritance, childlessness, sexuality, death, ancient cultures, cultural integrity and preservation of the environment. The article considers Simpson's 'anti-Gothic' approach to landscape in her novels, yet also shows how her 'realist' depictions of place evoke unease surrounding the issue of white belonging in Australia. Simpson's metaphoric self-identification with trees, particularly the Australian ironbark, is pivotal to the quiet power of her fiction's exploration of belonging in the Australian landscape.
\end{abstract}

\section{Landscape as witness, literature as place}

In three novels published in less than five years, Mr Wigg (2013), Nest (2014b) and Where the Trees Were (2016c), Inga Simpson explores and 'listens - to the world beyond the merely human' (Tredinnick 2007: 1), both to engage readers and also to locate herself in the 'landscape' of her past and present. Simpson's nature writing is inseparable from the places in which it is set and from their natural history. Characters in her novels, like Simpson herself, are fused with the landscape, particularly the trees that inhabit it. The story of each character is linked to trees in fundamental but distinct ways: in $\mathrm{Mr}$ Wigg, a fairy-tale thread centred on the personified fruit trees of Wigg's imagination mirrors the central storyline; in Nest, a fragile narrative of loss and betrayal is woven together through the idea of nesting and the healing power of trees; and in Where the Trees Were, unresolved tensions in black and white Australia are examined through an encounter with Wiradjuri burial trees discovered by children on a Central Western New South Wales property. In each case, trees represent both sacredness and spiritual wholeness.

Simpson's 'tree change' to the Sunshine Coast hinterland in 2006 coincided with a dedicated shift to nature writing, or the literature of place, and she has insisted that 'writing place well' is at the forefront of her creative agenda. In her 
essay 'Triangulation' (2016b: 295), Simpson links trees with her subjective life: 'Ironbarks are my heartwood. They cling to the hilltops and paddock edges in the dry land of my childhood.'

Ironbarks as their name suggests, are tough trees. Their outer covering is thick, rough and deeply furrowed. Dead bark is not shed but accumulates. As it dies, it is infused with kino, a dark red sap or gum. The kino ensures that the bark is impervious to fire and heat, protecting the living tissue within — one of the many adaptions of eucalypts ... In places, deep red oozes through like blood. Ironbarks grow in tough country, tolerating the dry. Their grey-green narrow leaves, turned sideways to the sun, are one of the features the early white explorers and settlers found so dreary and monotonous. (2016b: 295)

The presence of ironbarks form a backdrop to each of the novels to be discussed in this article.

Simpson's use of scientific names for trees and animals typifies her treatment of flora and fauna, revealing a close understanding of arboreal particularities and Australian landscape ecosystems. She shared with her father, a grazier and photographer, an interest in the microscopic details of the landscape and the science of trees, birds and other wildlife. Her father took close-up photographs of the ironbarks and other features on their rural property. He even built their family home from a huge ironbark he felled on their land. Simpson's appreciation of the landscape is thus tied to particular family connections, but also to more general notions of freedom and independence:

From twelve or thirteen, I camped out alone with the rocks, trees and stars ... There was a flattish site for a tent and a large stone fireplace overlooking crop and grazing land ... After sundown, my ironbark sentinels faded into dark ... By day, I wandered, collecting itchy seedpod boats from beneath kurrajongs to sail on the dam, where mistletoe-infected trees admired their own reflections ... I explore[d] the shade loving ferns and mosses and orchids - a secret world of green (2016b: 295)

Simpson's work fits within a nature writing tradition that traces its beginnings to various works of natural history from the later eighteenth century and through the nineteenth century, including Gilbert White's Natural Histories and Antiquities of Selborne (1789) (Mabey 2006: 2-6) and the poetry of William Wordsworth, a close student of the physical environment - plants, animals, geography and weather but also an imaginative shaper of sensory experience. Nature writing, however, came into its own as a genre when Henry David Thoreau began writing of life in his cabin on the edge of Walden Pond in his Life in the Woods (1854). For the first time, 'nature' was at the centre of a vision of the American psyche, prompting numerous other American authors to embrace the non-human world as a subject for description, analysis and reflection. Like Wordsworth's and Thoreau's writing, Inga Simpson's fiction tells us about Simpson, her reading and her subjective life just as much as it provides an objective vision of the natural world. But it certainly inherits from the natural history tradition an interest in a precise geographical location, its flora and fauna, and the seasonal changes, offering a close and meticulous observation made over a period of time. Simpson sees the landscape as a witness to history. 


\section{Nature writing and 'unsettled settledness'}

Simpson's childhood, steeped in the sclerophyll of the inland, is embedded in the often tough, yet not untender, syntax of her writing. This style denotes an unease that perhaps stems from a dilemma common to many non-Indigenous Australians: an intense love of land twinned with concerns about the consequences of their presence in it. Simpson's work challenges the way we live in, and on, an inherited landscape. Murray Bail (2013) argues that such unease in landscape-oriented Australian fiction is part of a coming to terms with place that is characteristic of New World experiences. This 'unsettled settledness' (Jacobs and Gelder 1998: 25; Offord and Haebich 2008: 3) is most evident in Where the Trees Were (2016c), but is present in Simpson's other novels too.

In Where the Trees Were, Jay[ne] - who, Simpson has said in a personal interview (Simpson 2016a), is a version of herself - is one of a group of primary school children growing up in the Lachlan Valley of New South Wales, who discover a stand of yellow box gums on her family's rural property:

There was one tree for each of us. As if they were for us. What breeze there was had been stilled. The birds and insects paused. For a moment, there was no sound ... I pushed past the others, to touch the ledge between the bark and the carved surface of the largest tree. The cuts were deep and wide, right into the heartwood, like fingers making a river. Scrolls and diamonds filled the space around it. It all meant something. It meant a lot. We knew straight away ... and we knew that we all felt the same, without having to speak. It was as if the trees said everything for us. (Simpson 2016c: 11)

One of these trees is an 'arborglyph' with intricate designs carved into the heartwood by the Wiradjuri people. Arborglyphs represented a map for a warrior's departed soul to navigate the afterlife. ${ }^{1}$ The discovery of the grove of trees, and the promises made by the friendship group there, connect the characters from Jayne's childhood throughout their lives. Simpson draws on the sacred power of the trees to symbolise shared promises, friendship and attachment to the landscape.

We learn in this novel, however, that the presence of such trees was regarded as a threat to land ownership and the living of white Australian farmers, and at the time of Mabo they were regarded as a threat to be destroyed. In the alternating interplay of present and past, Jayne, who has become an arts conservator based in Canberra, has committed an art crime - the return of an arborglyph from a Canberra museum to its rightful Indigenous owners - in order to somehow right the wrongs perpetrated by her family (but also by white Australia more broadly) in removing these living temples of Aboriginal culture from sacred groves across Western New South Wales. Jayne's efforts to overcome the mistakes of childhood put her career and relationship with Sarah, a senior member of a government department, at risk. The question the novel asks is not whether Jayne is guilty because she is: it is whether the author can employ the broader context in such a way as to balance Jayne's acts against the nature of the world through which she moves (Williamson 2016: 2). The novel is also about reverence and respect for trees and our collective responsibility as guardians of culture in the face of those wanting to tear down trees symbolic of ancient magic and rituals. Simpson's use of landscape, and the symbol of the sacred tree, is evidence of her working towards a correction of the complex, multi-faceted relationship of people with rural Australia. 
My conversation with Inga Simpson took place soon after heated debates about cultural appropriation had erupted, sparked by American novelist Lionel Shriver's polarising opening address at the 2016 Brisbane Writers Festival. I was interested in Simpson's views on this issue since she walked out of the speech, which she considered 'off-note, acerbic and rude', and as displaying an unawareness of the particular issues in play in contemporary Australia. In this same interview, Simpson revealed that when writing Where the Trees Were, she was intrigued by articles and drawings by early Australian writer, botanist and illustrator Louisa Atkinson, published in the Sydney Morning Herald and Illustrated Sydney News in the 1850s and 1860s (Simpson 2016a). Atkinson's views were ground-breaking for their sympathetic references to Australian Aboriginal people and for advocating conservation. Simpson undertook her own research into the existence of arborglyphs and, when the novel was complete, sent a draft to Dr Lawrence Bamblett, a Wiradjuri academic specialising in representations of Wiradjuri culture. Simpson wanted her account in the novel to deal sensitively with a 'tricky subject':

Dr Bamblett didn't go out of his way to teach me about the trees, but he was able to correct mistakes and misunderstandings I had made from referencing the work of white anthropologists, and directed me to the use of material that was accurate and authentic. (Simpson 2016a)

Simpson considers that it is important for all Australians to be able to participate in conversations about land and cultures, and that 'these conversations are not separate (black/white) conversations or monologues', so this was an important story to tell. Simpson well remembers the conversations she heard as a child about the Mabo judgment, and the Four Corners program referred to in Where the Trees Were (2016c: 100-2) that worried white Australian landholders. She refers to the impact of native title in an author's note to the novel:

Many arborglyphs were destroyed as part of the initial dispossession and clearing of Kamilaroi and Wiradjuri land for farming. Some were later cut down and removed for display in gardens, museums and galleries. There were still many in place as late as the 1960s. While some would have been lost to natural causes, as a child of the 1970s and 1980s, I remember some of the conversations around the introduction of Native Title. I can imagine what happened to the rest of those trees. (2016c: 300)

While these are complex issues, Simpson feels she is 'on firmer ground to write from a white settler point of view, as opposed to attempting to write characters from an Indigenous viewpoint' and that her 'story comes from lived experience, having experienced no consciousness about colour' as a young person growing up in Central Western New South Wales. The Wiradjuri boy in Jayne's fictional friendship group drew on Simpson's experiences of her time at school spent with both Wiradjuri and white children, a distinction that Simpson says was not discussed at the time, so she 'did not know these children were Wiradjuri' (Simpson, 2016a). As an adult, she feels a sense of guilt at 'how blanked out [she] was as a younger person to the cultural rift between black and white', and this sense permeates the story. In a review of the novel, Rhyll McMaster (2016:2) comments that while 'Simpson skirts around the edges', her intention is to convey an 'idea of guilt, assuaged through resuscitative action on behalf of [I]ndigenous people who remain 
strangely mute and without agency'. McMaster describes Simpson's characters as 'passionless, disconnected and existential', and the narrative as precariously 'weaving a bloodless tale around the ongoing dispossession of a people'. I take issue with McMaster's conclusion that there is no 'leap from exposition into reflection'. In my view, Simpson does succeed in shedding light on a story not widely enough known about the rights and wrongs involved in the removal, but also the repatriation, of Wiradjuri objects of significant cultural value.

\section{Simpson's 'anti-Gothic' stance}

Simpson's writing evokes a sense of freedom in the face of the land that runs counter to the alienation and strangeness evident in many other Australian novels. Her landscape is a positive force. In our interview (Simpson, 2016a), Simpson used the word 'realist' more than once to describe her work, specifically distancing herself from so-called 'Gothic' treatments of life in rural Australia in novels like Andrew McGahan's The White Earth (2004), Joan Lindsay's Picnic at Hanging Rock (1967), Kenneth Cook's Wake in Fright (1961), Evie Wyld's All the Birds, Singing (2013), or even Barbara Baynton's short stories of the late nineteenth and early twentieth centuries, which depict bush landscapes as alive and hostile. Simpson finds these treatments 'foreign' and 'works against them' because 'this is not the rural Australia I know ... this imported artificial landscape of human drama. The characters are not at home there' (Simpson, 2016a). Such Gothic representations of rural Australia do not reflect Simpson's own intimate experience of the landscape.

Yet her story-motifs do sometimes have a slightly Gothic feel. Nest (2014b), for example, is a novel about the mystery of two missing children, as well as a book exploring the psychology of love and grief and the role of the natural world in healing. Its main character, Jen, is a reclusive middle-aged ex-teacher and artist who has returned to where she was raised in the Sunshine Coast hinterland. Simpson confesses that there is a good deal of herself in the character. While Jen's day-today encounters with birds in the landscape take centre stage, it is outside events - particularly the disappearance of a local schoolgirl - that mirror for her the disappearance decades before of a close school friend as well as the unexplained loss of her own father. These events, together with the loss of a primary relationship, undermine her efforts to establish a peaceful and idyllic life. When writing this novel, Simpson herself was affected by the disappearance of Woombye teenager Daniel Morcombe and its impact on the community (Brown 2015; Simpson 2016a).

The theme of the lost child has been a particular obsession in Australian literature and art since the time of white settlement, as detailed by Peter Pierce in The Country of Lost Children: An Australian Anxiety (1999). This important book examines this theme in Australian narrative as part of a broader cultural pattern through an analysis of certain key texts. Australian fiction has tended to transform this motif into elements specific to Australia's distinctive imaginative space. In Lindsay's Picnic at Hanging Rock (1967), for example, several schoolgirls disappear with one of their teachers while picnicking at Victoria's gloomy and forbidding Hanging Rock. Their disappearance is followed by further tragedies and violent deaths, which transform the innocuous small community of Appleyard College into a place of horror and scandal. This motif of children being lost in the Gothic landscape of 
settler imaginations (Steele, 2010) contrasts with Simpson's approach, where the landscape is a force for good:

I wanted South East Queensland and the forested area where I live to be a major character. Like Jen I hear birdsong all day where I live. I didn't want to paint the bush in a Gothic way despite the disappearance. I wanted it to be a benign place where the main character is very comfortable. (Simpson, in Brown 2015: 2)

In Nest, the lost child plot reflects not only Jen's painful memories of the past her missing childhood friend Michael and the suspicious simultaneous disappearance of her father - but also a broader social anxiety about an uncertain future. However, there are also constant reminders in Nest of the power of the landscape to overwhelm human existence. Jen maintains her house on the forest fringe, imagining that if she ceased in these efforts, her house 'would soon rot and fall and begin its own journey back into the forest' (Simpson 2014b: 226).

Yet the forest is ultimately a place of recuperation and healing rather than of threat. At the beginning of the story, the gentle presence of trees is personified:

The trees gathered round, their trunks a steady grey-brown. Sometimes, she suspected they shifted closer during the night, just an inch or two, rearranging their roots around rocks and soil. (Simpson 2014b: 4)

Jen has fled to this remote location for healing from her troubled past, broken relationship and childlessness:

Now she was just a husk of a woman. Orphaned. Childless. Little more than bone and sinew and skin without feathers to hide beneath or a song to sing. (Simpson 2014b: 201)

Living close to the forest and watching and sketching birds at close range, Jen escapes into the natural world. She sets up a 'spider rig' (Simpson 2014b: 199) as a means of flying like a bird and becoming one with the landscape and birdlife. As Jen moves ever closer to the treetop canopy, the reader accompanies her on a journey to self-acceptance and peace. The writing is laden with bird imagery of empty nests and birds leaving, as well as Jen's own metamorphosis. Hanging like a bird in her own nest constructed of vines and bark, she realises that

it was a moment that approached, a shift in time. She stared at the tree's dead heart while she listened, and at last she understood she carried something dead inside her too (Simpson 2014b: 238).

It is this union with nature that brings Jen her weightlessness: 'She was breathing with the forest. She was forest' (Simpson 2014b: 244).

Thus, in Simpson's work, the reader is protected from the savage inhospitable land where characters are overcome by the menacing shadows and deep depression that figure in so much Australian Gothic fiction set in the bush. Simpson's landscapes are, instead, imbued with a sense of hope and characters draw on the power of their surroundings to overcome loss, death and injustice.

\section{A hinterland identity}

Simpson identifies as a nature or landscape writer in the same tradition as Tim Winton and Gillian Mears. Mears' capacity with the sentence, her lyricism and the 
imagery in her representation of rural landscapes coaxed Simpson towards realism. Mears' The Grass Sister (1995) and The Mint Lawn (1991) were particularly influential, feeding Simpson's own hankering to write (Simpson 2016a). Winton's treatment of the ocean - particularly the liminal space between land and sea had an impact too. Winton's work also speaks of his interest in 'spiritual retreat and contemplation in nature' (Winton 2015: 131). Like Winton, Simpson writes of places she knows and uses the vernacular. As I read Simpson, Winton's words were vivid in my mind:

I began to write about Albany and the people and places along the south coast. This was as much a matter of making do with what I knew as it was an ongoing act of homage to somewhere I loved. But in retrospect, I see I was trying to find a language for the presence of the past. I was coming instinctively to an understanding of the way geography shapes us, but also tacitly giving credit to the weight of time. When they move in and across a landscape, humans are wading through a shared past, surrounded at every turn by events and processes that will never be over ... (Winton 2015: 137-8)

Asked whether she regards herself as a regional writer, Simpson suggests instead that she is a hinterland writer, quite liking 'the idea [of hinterland] — that we are related to the coast but separate from its highways, malls and spreading estates' (Simpson 2016a). Her idea of a hinterland identity plays on the notion of a hinterland of thought (Simpson 2011). Nest (Simpson 2014b) alludes to the mix of a strong alternative community in the Eudlo/Palmwoods area, comprising a growing number of ex-professional retirees and traditional farming families and timber cutters, such as Jen's father. Organisations like Landcare, to which Jen and her friend Lil are committed, unite nature-loving community members in a venture to preserve the natural beauty of the hinterland, reflecting Simpson's own interests.

Simpson's move with her partner to a rural property in the Sunshine Coast hinterland, where she has been able to explore nature writing, has allowed her to find a 'path back to my true self, my best self'. Reading many male narratives in their cabin in the woods as part of a $\mathrm{PhD}$ in English literature 'fostered certain hermetic ways', and for a time this limited her sense of what was possible. However, Simpson's decision to write a lesbian protagonist in her third nature novel, Where the Trees Were (2016c) was a conscious move to portray lesbian characters heroically, and to:

write against stereotypes ... story allows us to reimagine our lives, alternate futures, other possibilities - more generous and inclusive societies. And as is the case for all minorities, literature empowers us, gives us visibility. We need more lesbian characters on the page, and we need them written in our own voice. (Simpson 2015: 3-5)

Reviewers of Simpson's novels speak about her 'light touch' (Pierce 2016: 2) and 'acute powers of observation' (Middleton 2014: 1). Geordie Williamson describes Simpson as a 'graceful, limpid writer; her sentences clean up after themselves, neatly laying out their mimetic wares.' (Williamson 2016: 2) However, Simpson's subtlety makes her moves 'through the ethical thickets' of her novels poignant for the reader, who is left pondering issues - environment, gender, sexuality, race that have risen organically to the surface. However, it is the lyrical authenticity of 
the places where the characters of Simpson's novels live that resonates. Places, and particularly trees with all their intricate details delivered, are in fact characters in each of the novels.

\section{The Tree of Life}

In Simpson's first nature novel, Mr Wigg (2013), the tree motif is used to connect the reader to a rich vein of metaphor in European fairy tale and fable. Simpson's work is heavily influenced by the wishing trees and sacred trees of folklore, history and literature, and her vivid fruit tree imagery links clearly to the iconographic and literary language of trees represented by the motif of the Tree of Life, often depicted in Renaissance culture, particularly the botanical and horticultural paradigms of sterility and fecundity related to pruning and regrowth, life and death. Simpson explains the importance of formative literature to her writing, including the rich tree-laden symbolism of The Lord of the Rings. There are references, too, to other books about fruit and fruit trees Simpson recalls from childhood: Tales of the Arabian Nights read beneath the pomegranate trees (2013: 107), the Greek myth of Hades tricking Persephone into eating six pomegranate seeds while in the Underworld (2013: 107) and Mr Wigg's recollections of his own wedding and of eating quinces with allusions both to Edward Lear's The Owl and the Pussycat and to the quince (commonly identified as the 'golden apple') that Paris awarded to Aphrodite in ancient Greece (2013: 93-4). Simpson draws on this tradition to symbolically link Mr Wigg's life to the lives of spiritual and fairy-tale trees - the Peach King in particular - owned and tended by characters from a mythological royal kingdom, who appear in his dreams. These visions offer him respite and retreat from a rapidly changing world and provide him with glimpses of seasonal eternity in the final year of his life as his health declines.

This novel is Simpson's favourite, because its main character is the one furthest from herself. Mr Wigg documents the last year in the life of a kind and sensitive country man - a widower mourning for a wife lost to cancer, for an estranged daughter living in the city and for his strained relationship with his son. The novel is set in 1971, on a small farm in the heart of stone-fruit country: all that remains of his family's once extensive New South Wales property. Yet the small details of Mr Wigg's life - tending his orchard, preserving fruit, welding, inventing, keeping chickens and enjoying visits from his grandchildren - connect him to his past and make life bearable. Simpson based the story on her childhood experience of visiting grandparents with an orchard: she remembers the richness of childhood, when there was freedom and a lack of fear, delicious home-grown food and quiet times spent watching the cricket interview (Simpson 2016a). The story is permeated with nostalgia for this simpler and slower life in step with the seasons and punctuated by pleasurable daily rituals that help to overcome loss and hurt. In a brief memoir published in the Queensland Writers' Centre journal, Writing Queensland (Simpson 2014a: 8), she observes:

The landscapes of childhood offer a rich vein to mine when writing place ... Specific smells and sounds, school yards, streetscapes and paddocks are imprinted on us. They are part of who we are. And yet so long ago (for me anyway) that it is almost a foreign country, taking on mythical proportions. Our memories are not necessarily complete or accurate but they go deep. 
However, Simpson consciously avoids 'pin[ning] the place down too much', so a series of impressions is created, and the reader is able to populate the landscape of the story with their own childhood recollections and emotions (2014a: 9). She is committed to placing readers in her book's settings. In this sense, Simpson has taken her cue from American writers like David Vann, whose stories testify to deep emotional connections with places linked to his early life and family history, and Annie Proulx, a place-based writer who develops story by asking herself what people do for a living in a particular place, and connecting the characters in her novels with authentic livelihoods and place-based emotional truths (2014a: 8).

To convey place, Simpson uses evocative imagery, layers of symbolism and metaphor, and personification - particularly of trees. She is interested in the magical properties of trees. In $\mathrm{Mr}$ Wigg, each variety of fruit tree in Mr Wigg's orchard is personified. For example, the Mulberry Tree is cast as a wise tree, a little like $\mathrm{Mr}$ Wigg himself:

It would be fair to say that the mulberry tree was a bit aloof. He was physically set apart from the others - position always determined so much about a tree - and their youthful boasting didn't interest him much. They might have sought advice from one who had grown for much longer, seen many more seasons, but this is the way of the young, thinking they know it all. The Mulberry, too, might have shared his rumbling thoughts on the meaning of bearing fruit year after year, or stories of some remarkable things he had seen. Instead, he stayed silent, having learned younger trees lacked the patience to listen. (Simpson 2011: 8)

There is a fine line between dream and reality for Mr Wigg, who talks knowingly to the trees as well as to his dead wife as he goes about the rituals of pruning and picking fruit. Magical elements are reflected in his character from the Peach King and Orchard Queen fables he dreams; he is an inventor who tells magical stories and knows the recipes for delicious childhood treats. He takes a year to weld the Peach Tree that wins the Fruit Festival Sculpture Award. It links his orchard life to lost love and a time forever gone, but also leaves a legacy for the future.

Simpson uses the tree metaphor to refer to Australian settlement, emphasising that the majority of Australians have been migrants or the descendants of migrants. $\mathrm{Mr}$ (Alneaus) Wigg's pastoral visions represent the dream of many Australians of European lineage who had never experienced at first hand the European landscapes of their forebears. Wigg was the name of Simpson's French great-great-grandfather (Simpson 2016a), and she recognised that her own grandfather in 1970s Australia 'was living that French village life that's centred on food and communal spaces even though he had not ever been there or experienced it' (Simpson 2016a; Simpson in Metcalf 2013: 2-3). In the novel, Mr Wigg sips tea and imagines villages and orchards in Europe - 'His family's chalky hills lined with vines' (Simpson 2013: 244) and the 'substantial' stone walls adorned with woodland strawberries that appear in his Orchards of the World book (2013: 254). The children of immigrants like $\mathrm{Mr}$ Wigg felt torn between the family traditions and imagined relationship to the places of their family's past, and their own yearning to belong in Australia. The orchard symbolises this link between two very different cultures.

There is sadness for the past in this novel and an aching nostalgia for simpler times when there was a stronger connection with the land and the seasons. Frequent references to food - whether corned beef sandwiches with pickled beetroot, 
homemade chutney or the fruit desserts with meringue, pastry or custard that remind readers of their own slower childhoods - also tie in with Simpson's observations that the pendulum is swinging back in locations like the Sunshine Coast hinterland, where small pleasures like growing fruit trees and enjoying organic food experiences are part of the area's ethos.

The self-sufficiency of which Simpson speaks reminded me of Kate Llewellyn's A Fig at the Gate (2014), which was motivated partly by the author wanting a 'garden that would feed me and my friends; back to what almost everyone had in their childhood, which was a garden that would partly sustain the family' (Llewelyn 2014: xv). Both Simpson's and Llewelyn's books celebrate human kindness. Thus $\mathrm{Mr}$ Wigg gives fruit to his son and the grape-growing Traubners next door, feeds his grandchildren nourishing food and even gives away bottles of peaches to the young electrician who comes to repair the wiring in his dilapidated house.

Simpson reminds us of trees and the orchard as a metaphor for life (2013: 158) and describes marriage as a garden with a life of its own, but sadly for Mr Wigg, 'no one had much advice when it was gone, though, nor could they help you with the pain. It just had to be borne, like a terrible winter, or drought. One that didn't ever end' (2013: 273). Mr Wigg is a book about confronting change, especially the unsettling experience for the elderly as they adapt in a rapidly altering world. Both the actual and fabled stories stem from the painful loss of a loved one. We feel $\mathrm{Mr}$ Wigg's inability to cope with loss:

How were you supposed to live without someone after fifty-odd years? The thought had seemed worse than death at the time, still did some nights, when he lay staring into the dark, but here he was all the same. Life had a way of going on whether you were interested or not, and then you felt yourself taking pleasure in a few small things, and a few more. (2013: 36)

In the face of this loss, the orchard is a place of safety. The swirling world of change outside is delivered via the radio and the television or by visiting the neighbours. Australia's national soundtrack of the 1970s - the Vietnam War 'Death Lottery' (2013: 63), the election of Idi Amin as president of Uganda (2013: 66) and the politicisation of cricket - with the cancelling of the South African cricket tour as a protest against apartheid (2013: 251) — plays in the background of Mr Wigg's life. Age-old farming traditions are disappearing in the face of modern technologies and new machinery. Yet, amidst these happenings, the seasons follow one another in the orchard as they have always done - although, as Mr Wigg ages, he loses his driver's licence and is forced to give up playing bowls, while advancing Parkinson's disease makes his hands tremble. Simpson has said:

There is a history to our land, going back to settlement like Mr Wigg's and being carved up over time, and not always amicably, among sons and brothers ... It feels like a decline, something sad, like the landscape in itself being farmed to death. (in Metcalf 2013: 3)

While social realist elements draw the reader's attention to the way we treat the elderly, the indignity of growing old and the injustices of inheritance, the stories of trees in the landscape as metaphors for human experience are the central theme of the book. 


\section{Living the landscape: The lyric of the country}

Simpson's stories have a sensual complexity that brings the landscapes of her history and imagination vividly into focus for her readers, particularly through the personification of trees. However, she also uses discrete occurrences in the lives of her characters to stimulate thinking in the intellectual terrains of occupation and dispossession, strains on the natural environment, the economic sustainability of rural communities and the challenges the landscape presents to us about responsibility and respect. Thus these are not only geographic landscapes, but often moral and spiritual ones. In the words of Mark Tredinnick (2003: 10), her novels are part of a burgeoning list of works of nature writing 'in which the lyrics of the country sing'. Introducing his edited collection of nature writing, A Place on Earth (2003), Tredinnick writes of pattern and music embodied in geographies that 'teach me how best to live the life that has been given to me' and explains that for him, nature writing is the transcription of landscape experience into both language and acts of love (Tredinnick 2003: 27). In a similar way, the novels that have been discussed in this essay are written out of the heart of the places Simpson knows, and they embrace their respective ecologies. As well as capturing the intricacy and wildness of Australian landscapes, the novels share straightforward, humble, ordinary pleasures about existing and participating in these natural environments. As she explains in her essay 'Triangulation' (Simpson 2016b: 303-4), she believes that this is made possible because she writes surrounded by bushland:

I am made of ironbark and stone. Formed on the hills scraped back to their bones. It is to the hills I have returned: the Sunshine Coast's sub-tropical hinterland thick with trees and loud with birdsong. At first, blinded by chaotic green, I didn't notice the ironbark. After heavy rain, I recognised their black trunks standing among the brush box, tallow-woods, bloodwoods, grey gums and flooded gums ... Sometimes I see them with my father's eye, calculating their diameter, the quantity of timber within, or the dimensions of a bowl turned from a crosssection ... It is no surprise, I suppose, that I gravitated towards the handmade cottage of timber, stone and recycled brick ... It is by the big ironbarks that I orient myself, get my bearings.

Inga Simpson's writing has come not only from herself but from her relationship with the land. This work advances the role of Australian fiction in honestly engaging in dialogues about place, time and belonging.

\section{Endnotes}

1 For thousands of years, the Wiradjuri and Gamilaroi peoples of Central Western, NorthWestern and North Coast New South Wales ceremoniously carved trees as a form of artistic and cultural expression. The trees usually were located near riverbanks and flats, where the excavation of soil was easier. Celebrated Aboriginal men were buried with the burial tree design facing the grave to serve as a warning to passers-by of the spiritual significance of the area. Each tree was uniquely carved, featuring geometric shapes, chevrons, curvilinear lines, scrolls and concentric circles, distinct from the 'dot' patterns used in Central and Western Australia (Briggs and Jackson 2011).

2 A spider rig is a form of adjustable double-ended lanyard that allows tree climbers to reach extreme heights from the ground, giving them the sensation of 'sky walking'. The concepts 
of the spider rig and Jen's 'tree bed' were sourced by Simpson from Richard Preston's The Wild Trees: A Story of Passion and Daring (2008) (Simpson 2014b: 297; Simpson 2016b).

\section{References}

Bail Murray 2013. 'Landscapes and emptiness'. 2013 Kenneth Binns Lecture, Canberra, 3 August, http://trove.nla.gov.au/work/183392359?q\&versionId=199770846.

Briggs Ronald and Jackson Melissa 2011. Carved trees: Aboriginal cultures of Western New South Wales. Sydney: State Library of New South Wales.

Brown Phil 2015. 'Author Inga Simpson draws on impact of Daniel Morcombe's disappearance to write new novel', Courier-Mail (Brisbane), 24 August, http://www.couriermail.com.au/news/queensland/author-inga-simpson-draws-onimpact-of-daniel-morcombes-disappearance-to-write-new-novel/news-story/ 8d6fceabc2212c216f3816641db7085a.

Cook Kenneth 1961, Wake in fright. New York: Text.

Jacobs Jane M. and Gelder Ken (1998). Uncanny Australia: Sacredness and identity in a postcolonial nation. Melbourne: Melbourne University Press.

Lindsay Joan 1967. Picnic at Hanging Rock. Melbourne: Cheshire.

Llewellyn Kate 2014. A fig at the gate: The joys of friendship, gardening and the gaining of wisdom. Sydney: Allen \& Unwin.

Mabey Richard 2006 [1986]. Gilbert White: A biography of the author of The natural history of Selborne. London: Profile Books.

McGahan Andrew 2004. The white earth. Sydney: Allen \& Unwin.

McMaster Rhyll 2016. 'Rhyll McMaster reviews Where the trees were by Inga Simpson'. Australian Book Review, April, https://www.australianbookreview.com. au/abr-online/archive/2016/178-april-2016-no-380/3128-rhyll-mcmaster-reviewswhere-the-trees-where-by-inga-simpson.

Metcalf Fran 2013. 'Inga Simpson opens a window on the past in evocative work Mr Wigg'. Daily Telegraph, 2 July, http://www.dailytelegraph.com.au/ entertainment/arts/inga-simpson-opens-a-window-on-the-past-in-evocative-workmr-wigg/news-story/f67fd05302e0562d8192552adf444c40.

Mears Gillian 1991. The mint lawn. Sydney: Allen \& Unwin.

Mears Gillian 1995. The grass sister. New York: Alfred A. Knopf.

Middleton Carol 2014. 'Inga Simpson's new novel: Nest'. Australian Book Review 365, https:/www.australianbookreview.com.au/compoent/k2/123-october-2014-no365/2173-inga-simpson-s-new-novel-nest.

Offord Baden and Haebich Anna 2008. 'Introduction: Landscapes of exile — "once perilous, now safe"'. In Anna Haebich and Baden Offord (eds), Landscapes of exile: Once perilous, now safe. Bern: Peter Lang, pp 1-4.

Pierce Peter 1999. The country of lost children: An Australian anxiety. Melbourne: Cambridge University Press.

- 2016. 'Where the trees were review: Inga Simpson's talents as a writer come to the fore'. Sydney Morning Herald, 29 April, http://www.smh.com.au/entertainment/ books/where-the-trees-were-review-inga-simpsons-talents-as-a-writer-come-to-thefore-20160422-goco9x.html.

Preston Richard 2008. The wild trees: A story of passion and daring. New York: Penguin. 
Simpson Inga 2011. 'Hinterland'. Inga Simpson (weblog), http://www.ingasimpson. com.au/? $\mathrm{p}=475$.

— 2014a. 'In an emotional place'. Writing Queensland 245 (October): 8-9.

— 2013. Mr Wigg. Sydney: Hachette.

- 2014b. Nest. Sydney: Hachette.

— 2015. 'Focus on lesbian/queer Australian women writers: Guest post'. Australian Women Writers Challenge [weblog], http://australianwomenwriters. com/2015/10/focus-on-lesbianqueer-australian-women-writers-guest-post-by-ingasimpson.

— 2016a. Personal interview with author. Palmwoods, Queensland.

— 2016b. 'Triangulation'. Griffith Review 52: 295-304.

- 2016c. Where the trees were. Sydney: Hachette.

Steele Kathleen 2010. 'Fear and loathing in the Australian bush: Gothic landscapes in Bush studies and Picnic at Hanging Rock'. Colloquy 20: 3-56, http://artsonline. monash.edu.au/wp-content/arts/files/colloquy_issue_20_december_2010/steele.pdf.

Thoreau Henry David 1854. Life in the woods. Boston: Ticknor and Fields.

Tredinnick Mark (ed.) 2003. A place on earth: An anthology of nature writing from Australia and North America. Sydney: UNSW Press.

2007. 'Catching the lyric of the country: A taxonomy of Australian nature writing', 28 October, http:/www.marktredinnick.com.au/index.php/writing/ more/catching-the-lyric-of-the_country.

Williamson Geordie 2016. 'Inga Simpson's Where the trees were a subtle journey through time'. The Australian (Review), 11 June, http://www.theaustralian.com.au/ arts/review/inga-simpsons-where-the-trees-were-a-subtle-journey-through-time/ news-story/1d7a694d8ccbec1ffbe59badf7545962.

Winton Tim 2015. Island home: A landscape memoir. Ringwood: Penguin.

Wylde Evie 2013. All the birds, singing. London: Jonathan Cape. 